https://doi.org/10.18485/iipe_response2covid19.2021.ch4

\title{
THE GLOBAL ROLE AND AMBITIONS OF THE EUROPEAN UNION - BEFORE AND DURING THE COVID-19 PANDEMIC ${ }^{1}$
}

\begin{abstract}
Jelica Gordanić ${ }^{2}$
Abstract: Before the COVID-19 pandemic, the global role of the EU had been seriously challenged for multiple reasons: the diversity of interests of the member states, the crisis of European identity, Brexit, lack of military power, complex decision-making process, dependence on the US, etc. The outbreak of COVID-19 and an inadequate response by the EU damaged its reputation and slowed down its global influence and ambitions. EU citizens are losing trust in the EU institutions. On the other hand, China and Russia have been using vaccine diplomacy to develop their soft power and global influence. China and Russia have enlarged their influence in the Balkans, the Eastern Partnership countries, Asia, the Pacific region, and Latin America. Compared with these countries, the EU is losing the characteristics of a global actor. The paper examines to what extent the EU's role as a global actor has been damaged during the COVID-19 pandemic and what the EU can do to overcome the crisis caused by COVID-19. The paper concludes that the EU should intensively work on its internal problems and its role as a military force and dependence on the US. The inadequate response of the US to the COVID19 pandemic gives the EU space to become a new leader in the transatlantic world. Keywords: EU, COVID-19, pandemic, China, Russia, the US, global ambitions, global role.
\end{abstract}

\footnotetext{
${ }^{1}$ The paper presents findings of a study developed as a part of the research project "Serbia and challenges in international relations in 2021", financed by the Ministry of Education, Science, and Technological Development of the Republic of Serbia, and conducted by Institute of International Politics and Economics, Belgrade.

${ }^{2}$ Research Fellow, Institute of International Politics and Economics, Belgrade, Serbia, jelica@diplomacy.bg.ac.rs.
} 


\section{INTRODUCTION}

The paper analyses the global role and ambitions of the European Union (EU) before and during the COVID-19 pandemic. In the period before the pandemic, the global role of the EU had been challenged due to Brexit, the crisis of European identity, lack of military power, the dependence on the US, the economic rise of China, etc. The EU has lost one seat in the UN Security Council as a result of Brexit. Besides the progress of the Common Security and Defence Policy (CSDP), NATO remains the most recognizable actor in European security.

In the first part of the paper, the author deals with the obstacles standing on the EU's way to become a strong global actor. The author pays attention to the successful developments of A Global Strategy for the European Union's Foreign and Security Policy (EU Global Strategy), as well as the weakened role of the EU in the United Nations and its lack of military power and dependence on NATO and the US.

In the second part of the paper, the author analyses the impact of the COVID19 pandemic on the global role and ambitions of the EU. At the beginning of 2020, the EU was preparing for Brexit negotiations, the elections of the president of the United States, talks over the next seven-year budget of the Union, the German presidency of the European Council and the Conference on the future of Europe. The outbreak of the COVID-19 pandemic affected the political priorities and global ambitions of the EU and pointed out the vulnerability and strategic loneliness of the EU. The COVID-19 pandemic caused significant damage to the reputation of the EU at both internal and external levels. EU citizens are losing trust in the EU institutions. On the external level, the pandemic crisis has challenged the place of the EU in the world and its relations with the other global actors - the US, China, and Russia. The paper examines to what extent the EU is damaged by the COVID19 crisis and whether it has the capacity to become a global actor after the crisis.

\section{GLOBAL AMBITIONS OF THE EU AND OBSTACLES STANDING ON ITS WAY}

Today's multipolar world is a good opportunity for the EU's positioning as a global actor. The EU has proven to be one of the most powerful regional actors in the world. The rise of the global political ambitions of the EU has caused a lot of public and academic attention. A Global Strategy for the European Union's Foreign and Security Policy (EU Global Strategy) from 2016 introduces and highlights priorities of the EU on the global level:

- the security of the Union,

- state and social resilience to the East and the South,

- an integrated approach to conflicts and crises, 
- cooperative regional order, and

- global governance for the 21st century.

In the period before the COVID-19 pandemic, the implementation of the EU Global Strategy has shown progress on many levels: European security and defence, the reaffirmation of the perspective for the Western Balkans; the goal of strategic autonomy as set out by the Council; preserving the nuclear deal with Iran; the step change in the partnership with Africa and strong support of the UN reforms. In achieving its global ambitions, the EU has established a successful net of inter-regional and bilateral trade agreements and with almost all important economies and regions of the world. During the tenure of the Juncker Commission, 2014-2019, the EU concluded trade agreements with Canada, Japan, Vietnam, Singapore, and the MERCOSUR countries, Brazil, Argentina, Paraguay, and Uruguay (Roloff, 2020, 33). Also, the EU has deepened its partnerships with the Middle East and North African states and regional organizations like the League of Arab States, the Organization of Islamic Cooperation, and the Gulf Cooperation Council (EEAS, 2019. p. 10).

While expanding its global role and ambitions, the EU has been confronted with a number of serious challenges, including the migrant crisis, Brexit, member states' disagreements on political issues, China's economic rise, a crisis of European identity, and so on. Weak foundations of the European identity in the moments of crisis (like the migrant crisis or the COVID-19 crisis) "causes the gradual awakening of the national identities of the member states" (Gordanić, 2019, p. 11). Eurosceptics raise the question of to what extent the process of European integration threatens the national identities of the member states.

The key factor in the successful global role of the EU is the unity of its member states. But, maintaining unity is a very difficult task for the EU, having in mind its members' disagreements on controversial political issues like the migrant crisis, Ukraine, Kosovo, Turkey, etc (Lopandić and Gordanić, 2021, p. 180). The EU is a sui generis actor in the system of international relations. It is a one-of-a-kind actor, a hybrid of state and international organization. By its characteristics, the EU is a supranational organization in which member states share sovereignty. Some of the EU's biggest rivals on the global level are states like the US, China, Russia, and new emerging powers like Brazil and India. Unlike the EU, states do not have a problem achieving and maintaining unity on important political or economic issues. The unique features and sui generis nature of the EU, combined with a complex institutional structure and decision-making process, can be considered a serious obstacle to achieving its global role and ambitions. 


\section{BREXIT - ONE SEAT LESS IN THE UN SECURITY COUNCIL FOR THE EU}

Besides the above-mentioned problems, the EU has been facing one new problem at the global level - Brexit. After Brexit, the EU lost the third-largest member state, $14.8 \%$ of its GDP, the largest stock of foreign direct investment, and the second-largest net contributor to the common budget. Theorists consider that the EU without Britain will be smaller, poorer, and less influential on the world stage (Tudoroui, 2018, p. 112).

As a consequence of Brexit, the EU lost one of its two member states with permanent seats on the UN Security Council (UNSC) as well as the benefits of the UK's considerable diplomatic networks and skills. France was left as the only EU's permanent representative at the UNSC and the only veto power. Other $26 \mathrm{EU}$ member states can become non-permanent members of the UNSC for a period of two years.

Brexit may be an opportunity for EU members to improve their approach to UN diplomacy. France, for example, will have to balance the privilege and burdens of being the only EU member with a permanent seat in the Security Council. Germany will need to take a clearer leadership role in UN affairs. Other European states and the European External Action Service (EEAS) will also have to become more active to fill the gap Brexit creates - potentially leading to an increase in European diplomatic activism at the UN (Gowan, 2018). Brexit has the potential to cause a lack of trust between the UN and the UK in the future, as well as the potential to deteriorate cooperation between the UK and France in the Security Council (SC).

With the aim of compensating for its reduced status in the UN after Brexit, the EU should rely on Article 34 of the Treaty of the European Union, which states: "The Member States shall coordinate their actions in international organizations and at international conferences. They shall uphold the Union's positions in such forums." The EU gained enhanced observer status in the UN General Assembly in 2011. The enhanced observer status is "an opportunity for the EU to achieve unity of its member states on important political issues" in order to set the basis for future global ambitions (Gordanić, 2017, p. 17).

\section{THE EU AS A MILITARY FORCE?}

One of the key issues standing in the way of the EU's global role and ambitions is the lack of military power. The EU is an actor that combines the characteristics of soft and normative power, based mainly on its economic power and political system. At the same time, the EU entails very limited characteristics of military hard power. 
Despite being one of the world's biggest economic powers, as well as one of the strongest normative and civilian power, "the absence of actual military hard power does not allow the EU to be an equally great power - like the US and China - in all dimensions of international politics" (Papanikolaou, 2020, p. 8).

The relationship between the EU and NATO is a complex one. Besides sharing 21 member states, cooperation between the EU and NATO has been often challenged due to the EU-Turkey relations, with Cyprus as a complicating factor. As a NATO member, Turkey often blocks various cooperative actions between NATO and the EU (Emerson, Balfour, Corthaut, 2011, p. 104).

Besides some of the EU's military successes and the progress of the Common Security and Defence Policy (CSDP) from soft to hard power peacekeeping missions and the formation of the Permanent Structured Cooperation (PESCO), the EU is not yet considered a military force. PESCO has been characterized as a project created more for political reasons rather than concrete security ones. Because of that, for the moment, it is NATO, not PESCO, which is defending Europe (Apetroe, 2018, p. 264). Theorists consider the US to be military force number one and NATO as the backbone of European security (Lopandić and Gordanić, 2021, p. 182).

Even before the COVID-19 pandemic, the relationship between the US and the EU was a challenging one. During the Trump administration, the US made it clear that those who have not contributed enough cannot count on the support of the US. The US has switched its focus to Asia and China. Europe is no longer priority number one. The COVID-19 crisis has the potential to cause negative strategic consequences for the transatlantic relationship. Theorists consider that COVID-19 has already added significant strains on US-Europe relations at a time when Washington is reviewing its global force posture. With the global economic recession likely to impact defence spending on both sides of the Atlantic, tensions over NATO burden-sharing could soar and further affect Washington's ability and willingness to remain the ultimate guarantor of Europe's security (Billon-Galland, 2020, p. 2).

\section{THE ARRIVAL OF THE COVID-19}

The COVID-19 pandemic has been a global political and geopolitical test. It has affected healthcare systems, economies, and governance of all states of the world. The COVID-19 pandemic has the capacity to cause the most serious global crisis since the Second World War.

The pandemic and its consequences have been dramatic for the most important global actors. Despite the fact that crises such as the pandemic are expected to improve international cooperation and strengthen multilateralism and interstate cooperation, the major global actors have decided to act unilaterally with the aim 
of defending their interests. The pandemic crisis has shown the lack of international cooperation on the global level. The COVID-19 crisis has become a powerful tool for the major global actors, the US, China, and Russia, to improve their soft power and prove their dominance in international politics. Some of them, like China, are doing an impressive soft-power job. Some of the global actors did not start well in the COVID-19 struggle. The European Commission has already accused Russia and China of taking advantage of the pandemic to engage in targeted influence operations and disinformation campaigns in the European Union (EU), with the goal of weakening European democratic systems. (Billon-Galland, 2020, 1).

The pandemic has deepened the rivalry between the global actors. In this notso-much-silent conflict, the EU has found itself in an intermediate position between other global actors. Theorists have been wondering: Has the COVID-19 crisis amplified nationalist trends, which have deepened rifts and further damaged cooperation and multilateralism? Is the EU able to fit into the world of power politics? (Martin, 2020, p. 3).

\section{THE COVID-19 PANDEMIC AND THE EU - LOSS OF TRUST OF THE MEMBER STATES}

The COVID-19 pandemic, coupled with the weakened position of the EU at the UN, internal problems, and the lack of military power, puts the global role and ambitions of the EU into question, as well as its ability to fit into a world of power politics. The pandemic has revealed Europe's dependencies on certain products, critical materials, and value chains.

The effects and consequences of the pandemic crisis are multi-layered for the EU. They can be considered as:

- a trust test between the $\mathrm{EU}$ and the member states.

- a resilience test for the EU and its member states, which are positioned between other global actors - China, the US and Russia.

- a test of the global role and global ambitions of the EU.

What was the EU response to the COVID-19 pandemic? Can it be considered strong and leading? The EU's contribution to fighting COVID-19 was initially limited. A Treaty of the EU limits the EU's competencies in public health. Health and borders are strictly national powers, which means that it was unclear how the EU could collectively respond to the pandemic. The EU states are too integrated to manage the crisis separately, but not integrated enough to manage it collectively (Lehne, 2021). The absence of cohesion between the member states and the European 
institutions was noticeable. Theorists consider it "a major sign of European weakness in managing crises." (Papanikolaou, 2020, p. 8).

The COVID-19 crisis has shown the European public a reality that Europe is alone and vulnerable. A large number of EU citizens think that the EU has slipped into irrelevance in the coronavirus crisis. In the survey conducted by the European Council on Foreign Relations (ECFR) in June 2020 among citizens of almost all EU member states, there was a sense that their country was left by itself in dealing with the pandemic. EU citizens reported that their perception of EU institutions has deteriorated, with those reporting that it has not improved outnumbering those reporting that it has improved. (Dennison, Zerka et al, 2020, pp. 2-3).

In every surveyed country, at least one-quarter of respondents said that their perception of the EU had worsened. The pandemic crisis and the lack of a European response were strongly associated in some member states with the lessons learned from the European debt crisis (2010-12) and the refugee crisis (2015). Even in the members who are historically Europhiles, like Spain, half of the respondents declared that their view of EU institutions had deteriorated. On the same question, 63 per cent of Italians and 61 per cent of French people said that the EU has not lived up to its responsibilities. (Dennison, Zerka et al, 2020, p. 10).

Citizens of Spain and Italy experienced lack of solidarity from the European Union and other member states as regards the supply of medical equipment and the closing of the Union's internal borders. In Italy, the initial stage of the COVID-19 crisis caused an unprecedented crisis of confidence towards the European Union: 72 per cent of Italians considered that the EU did not help during the crisis (Martin, 2020, pp. 6-7).

The COVID-19 crisis is not only a public health crisis for the EU. It is also a crisis of European integration, European identity, and European unity. Instead of growing solidarity in the time of crisis, the EU was returning one step backwards compared to the problems it had before the COVID-19 pandemic. Internal problems and a more profound crisis of European integration and identity overlapped with the problems related to the global role and ambitions.

The EU cannot be a strong global leader if its unity is in crisis. The results of the survey conducted by the ECFR show that EU citizens have lost trust in the EU institutions. This is not a good sign for the reputation of the EU. Other global actors can and will use these circumstances to diminish the role of the EU as a global actor and its global ambitions. The EU is currently in a situation that requires strong support and cooperation within the EU members and institutions. Citizens believe that the crisis has shown the necessity for greater cooperation within the $\mathrm{EU}$ (Dennison, Zerka et al, 2020, p. 13). 
A positive step forward in reviving the reputation of the EU was the agreement on a EUR 750 billion recovery plan to help the EU handle the crisis caused by the COVID-19 pandemic and on a EUR 1074 billion long-term EU budget for 2021-2027 (European Council, 2020). According to the conclusions of the European Council, the European Commission will borrow from the capital markets the amount of EUR 750 billion in 2018 prices to be allocated to the member states as loans ( 360 billion) and grants (390 billion) to overcome the pandemic crisis. The borrowing process will end in 2026. Loans will be repaid by the end of 2058 at the latest. In addition, EUR 1,074 billion will be spent as part of the budget of the EU, making the total spending for the 2021-2027 period 1,824.3 billion (Papanikos, 2021, p. 87). The first measure is called Next Generation EU (NGEU), and the latter is the Multiannual Financial Framework (MFF).

\section{OTHER GLOBAL ACTORS AND COVID-19 -A BETTER RESPONSE TO THE PANDEMIC THAN THE EU'S?}

The pandemic crisis has shown the lack of international cooperation and deepened rivalry between the major global actors. The pandemic has shown very assertive power politics led by China, Russia, and the US. European Council's President Charles Michel stated: "We should not let ourselves be misled by China and Russia, both regimes with less desirable values than ours, as they organize highly limited but widely published operations to supply vaccines to others" (Leigh, 2021).

China's government saw the pandemic as an opportunity to exert its international leadership and influence. It has managed to turn the crisis into a diplomatic and strategic opportunity, to increase its soft power and to improve its role as a global actor. The demonstration of the soft power of China in the form of donations of healthcare equipment to the member states of South and East Europe has caused suspicion in the EU about the intentions of China. Also, Chinese donations of healthcare equipment to the EU member states might be considered a sign of European weakness and lack of power (Papanikolaou, 2020, 11). Despite multiple Russian internal problems, the Kremlin has not forgotten the international domain. Moscow "has lost no time in seeking to flex its soft power muscles, sending "humanitarian aid" to a number of Western countries" (Mikhelizde, 2020, p. 3). Theorists consider Russia's response to the COVID-19 pandemic as "hardship at home, soft power flexing abroad" (Mikhelizde, 2020, p. 3).

At the beginning of the pandemic, the EU was criticized for the slowness of its own vaccination process, supply shortages, delivery bottlenecks and concerns about the safety of the vaccine. In the meantime, the EU has taken its critics seriously and become one of the leaders in vaccination. Around $70 \%$ of the EU's adult population 
have been fully vaccinated against COVID-19. The EU overtook the US in vaccinations. Its vaccination campaigns expanded faster than anywhere else in the world (Peltier, 2021).

But the shaky beginning of the EU vaccination process was an opportunity that fitted the strategic narratives of Beijing and Moscow. China was trying to prove the superiority of the Chinese model of governance as opposed to the model of Western liberal democracies. Some theorists consider China and Russia "as adversarial regimes vested in undermining the transatlantic alliance" (Corke, 2020, p. 3).

China and Russia gave the EU a powerful lesson on its own territory. During the COVID-19 pandemic, both countries gained supporters of right-wing populist parties from the EU member states, especially from Bulgaria, Italy and Poland (Dennison, Zerka et al, 2020, pp. 8-10).

The EU member states of Hungary and Slovakia have already turned to Beijing and Moscow for additional supplies of the COVID-19 vaccines. The Czech Republic, Austria, as well as some other EU member states, have shown an interest in the Russian vaccine and have held negotiations with Moscow about acquiring Sputnik $V$ once it has been evaluated by the European Medical Agency (EMA). The European Commission has been criticized for being too bureaucratic in its approach to vaccine contracts and for focusing on AstraZeneca, which has ended up seriously defaulting on delivery to the EU. Sebastian Kurtz, Chancellor of Austria, accused the EMA of being too slow to approve the Russian vaccine (Adler, 2021).

During the pandemic, China and Russia have positioned themselves as serious competitors to the EU in terms of influence and medical supplies over the Balkans and Eastern Partnership countries. Their vaccine exports, especially in Serbia, came with soft-power messages, praising mutual friendship and criticizing the EU for not helping when it was needed the most. Most of the Balkan countries, except Serbia, have difficulties obtaining the vaccines. Following the success story of Serbia, the other Western Balkans nations are considering turning to China and Russia for vaccines. The EU is losing the vaccine battle against China and Russia in the Balkans region. The EU delivered some vaccines to the regions of the Balkans and Eastern Partnership countries, but China and Russia had done it long before (Stojanović, 2021).

China has had impressive vaccine diplomacy compared to the other global actors. By mid-May of 2021, China exported more than 250 million doses overall or 42 per cent of its total production. The United States exported only 3 million doses or about 1 per cent of its production. That is quite an impressive statistic for China. More than half of China's total exports, about 165 million doses, have been administered in Latin America. After the decision of the Biden administration not to lift an export ban on raw materials for vaccines for Latin American countries, the 
soft power and influence of China have become even more relevant in this region (Stuenkel, 2021).

The Russian vaccine plays an important role in developing countries, which do not have their own vaccine programs and have been unable to compete with wealthier countries for more desirable vaccines. So far, more than 60 countries have approved the Russian vaccine Sputnik V. The public in the EU thinks that Russia is trying to employ the vaccine as a political tool globally to insert instability, division, and polarization in the political scene. They see vaccine diplomacy as a way for Russia to implement its existing strategy to encourage division in Western countries in order to weaken them. (Bateson, 2021).

Unlike China and Russia, which have used the pandemic as a tool to increase their global political influence, the US lost part of its reputation and global role during the pandemic. Theorists consider that the US' lack of support for international efforts to fight the COVID-19 pandemic represents "the biggest absence of US leadership since it emerged as a super power in World War II" and that it "reflects more than simply failure" (Corke, 2020, p. 4).

The EU is not yet considered a military force at the global level. It is still dependent on the US within NATO. With the vulnerable global role of the US during the pandemic and the US-China strategic rivalry before the pandemic, the EU should take more care about its own security. Perhaps for the first time in a long time, the EU should consider its future perspectives and relations in a triangle of strategic transatlantic dialogues: EU-US, EU-NATO, and NATO-US (Roloff, 2020, p. 35). Also, one of the main challenges for the EU in the post-pandemic world will be to review its own global place and its relations with the global actors, China and Russia, who have improved their global power during the pandemic.

\section{CONCLUSION}

Even before the COVID-19 pandemic, the global role and ambitions of the EU have been challenged due to the crisis of European identity, Brexit, the lack of military capacities and the dependence on the US. The EU Global Strategy from 2016 had the potential to become a possible fresh start of the EU Common Foreign and Security Policy and a factor of empowerment of the EU's global ambitions. But the reality, however, was not in the EU's favour.

The COVID-19 pandemic has significantly slowed down the global ambitions of the EU. On the internal level, the pandemic has been handled uncoordinated and inefficiently. EU citizens have lost trust in the EU institutions. On the other hand, powers like China and Russia have been using the pandemic as a strategic opportunity. These two countries significantly improved their reputations, influence, 
and status as global actors. They have spread vaccine diplomacy to almost all regions of the world - Latin America, the Balkans, the Eastern Partnership countries, Africa, Asia, and the Pacific. For China and Russia, the pandemic has been an excellent strategic opportunity, especially for China. Having in mind the global success of China and Russia during the pandemic, the question is: What has been left for the $\mathrm{EU}$ and its global role and ambitions? What are the global perspectives of the EU after the pandemic?

European foreign policy is entering an era of redefinition. Some theorists consider that Europe and the United States need to have a shared understanding of the risk that Russia and China pose to the multilateral system. They should focus on formulating a coherent, collective, and nuanced response that requires assessing Chinese and Russian influence operations against core US and European interests as well as political and economic vulnerabilities (Corke, 2020, p. 13). Perhaps, with the aim to start over with its global ambitions, the EU should make some changes in its modus operandi, instead of considering China and Russia as a threat. The EU needs to define its bilateral relations with the US, China, and Russia (Gaub and Boswinkel, 2020, p. 50).

The COVID-19 crisis might bring some new strategic conclusions for the EU in order to improve its global role and ambitions. The EU has proven to be a strong figure on a global level. After difficulties in the vaccination process, the EU is now one of the global leaders in vaccination with $70 \%$ of vaccinated adult citizens.

The EU should focus on restoring its integrity and European identity. Having in mind member states' disagreements during the pandemic, this is not going to be an easy task. The EU has been quite dependent on the US. To fulfil its own global ambitions envisaged in the EU Global Strategy, the EU should focus on becoming more independent from the influence of the US. It should develop its military capacities and reconsider its relationship with NATO. Also, the EU Global Strategy has shown significant progress in the economy and trade agreements. On the regional level, the EU has long been respected as an economic giant. In the period after the pandemic, the EU should focus on the re-development of its economic ambitions at a global level.

The period after the pandemic is going to be challenging for the EU. After the Euro crisis and migrant crisis, the pandemic crisis is a third serious challenge for the EU in a short period. After the global success of China and Russia during the pandemic, the global influence and ambitions of the EU are under question. Perhaps the EU will never have the reputation of a global actor as it currently has as a regional actor, but it should not give up its global role and ambitions. In order to focus on the Global Strategy's goals, the EU must address internal challenges, reduce its reliance on the US, and evaluate its future relations with China and Russia. 


\section{REFERENCES}

Adler, K. (2021, March 13). EU closes ranks over Covid surge and vaccine delays, retrieved from https://www.bbc.com/news/world-europe-56361840. Accessed 29 June 2021.

Apetroe, A. C. (2018). Making sense of the (post-)Brexit EU: Security, stability and the future of EU's collective security, CES Working Papers, 10(3), pp. 251-270.

Bateson, I. (2021, May 6). Germany, Russia and the Sputnik V vaccine- a tale of soft power, retrieved from https://www.dw.com/en/germany-russia-and-thesputnik-v-vaccine-a-tale-of-soft-power/a-57453387. Accessed 10 July 2021.

Billon-Galland, A. (2020). COVID-19 and the defense policies of European states, NATO Defence College Policy Brief, pp. 1-4.

Corke, S. (2021). COVID-19 Pandemic Recovery: If the US and Europe Find the Will, Multilateralism Is theWay, IAI Papers, 20 (40), pp. 1-18.

Dennison, S., Zerka, P., et al. (2020). Together in Trauma: Europeans and the World After Covid-19, European Council on Foreign Relations, Policy Paper, pp. 1-68.

EEAS. (2016). A Global Strategy for the European Union's Foreign and Security Policy. 28 June (European External Action Service, Brussels).

EEAS. (2019). From vision to action: The EU Global Strategy in practice: Three Years on, looking forward. (European External Action Service, Brussels).

Emerson, M., Balfour, R., Corthaut, T., et al. (2011). Upgrading The EU's Role as Global Actor. Brussels, Centre for European Policy Studies.

European Council. (2020). A recovery plan for Europe, retrieved from https://www.consilium.europa.eu/en/policies/eu-recovery-plan/. Accessed 5 September 2021.

Gaub, F., Boswinkel, L. (2020). How Covid-19 changed the future- Geopolitical implications for Europe. Paris: European Union Institute for Security Studies.

Gordanić, J. (2017). Posmatrački status Evropske unije u Generalnoj skupštini Ujedinjenih nacija [Observer status of the European Union in the General Assembly of the United Nations], Evropsko zakonodavstvo, No. 61-61, pp. 9-19.

Gordanić, J. (2019). Pad multikulturalizma kao faktor jačanja nacionalnog identiteta država članica EU [The decline of multiculturalism as a factor in strengthening the national identity of the EU member states], Međunarodna politika, 1175, pp. 5-21.

Gowan, R. (2018, May 8).Separation anxiety: European influence at the UN after Brexit. Retrieved from https://ecfr.eu/publication/separation_anxiety_european _influence_at_the_un_after_brexit/. Accessed 29 June 2021. 
Leigh, M. (2021, April 27). Vaccine diplomacy: soft power lessons from China and Russia?, retrieved from https://www.bruegel.org/2021/04/vaccine-diplomacysoft-power-lessons-from-china-and-russia.Accessed 8 July 2021.

Lehne, S. (2021, April 8).Why Can't Europe Cope with the Coronavirus?, retrieved from https://carnegieeurope.eu/strategiceurope/84286. Accessed 18 June 2021.

Lopandić, D., Gordanić, J. (2021). The European Union between its regional role and its global ambitions in international relations, in: K. Zakić\& B. Demirtaş, B. (eds). Europe In Changes: The Old Continent at A New Crossroads (pp. 173-186). Belgrade: Institute of International Politics and Economics, Faculty of Security Studies at the University of Belgrade.

Martin, E. A. (2020). COVID-19 Reveals Europe's Strategic Loneliness, IAI Pappers, No. 20(40), pp. 1-21.

Mikhelidze, N. (2021). Russia and the COVID-19 Crisis: Hardship at Home, Soft Power Flexing Abroad, IAl Commentaires, April 2020, pp. 1-6.

Papanikolaou, K. (2020). What Kind of Power?How The Covid-19 Crisis Affects the Orientation of the EU as a Global Actor. Brussels, Institute of European Democrats.

Papanikos, G. T. (2021). The European Union's Recovery Plan: A Critical Evaluation, Athens Journal of Mediterranean Studies, 7(2), pp. 85-102.

Peltier, E. (2021, August 31). 70 percent of adults in the European Union have been fully vaccinated, retrieved from https://www.nytimes.com/2021/08/31/ world/eu-covid-vaccinations-70-percent.html. Accessed 5 September 2021.

Roloff, R. (2020). COVID-19 and No One's World, Connections, 19 (2) The Security Impacts of the COVID-19Pandemic, pp. 25-37.

Stojanović, D. (2021, May 4). EU delivers vaccine jabs to Balkans after China and Russia, retrieved from ttps://apnews.com/article/china-russia-europecoronavirus-vaccine-coronavirus-40effa1bac402a9d9b6413077f914023. Accessed 1 July 2021.

Stuenkel, O. (2021, June 11). Vaccine Diplomacy Boosts China's Standing in Latin America, retrieved from https://foreignpolicy.com/2021/06/11/vaccinediplomacy-boosts-china-in-latin-america/. Accessed 1 July 2021.

Tudoroui, T. (2018).Brexit, President Trump, and the Changing Geopolitics of Eastern Europe. Cham: Palgrave Macmillan. 